\title{
Research Square \\ The Reverberation of Corona Pandemic in Developing Countries Special Reference To Ethiopia
}

\author{
Abebe Temesgen Ayalew ( $\nabla$ teabeman@gmail.com ) \\ Arba Minch Water Technology Institute, Arba Minch University \\ Elsabet Getachew Aynalem \\ Arba Minch University
}

\section{Research Article}

Keywords: COVID 19, Susceptibility, Impact Assessment, Statistical Analysis, Ethiopia

Posted Date: June 30th, 2021

DOI: https://doi.org/10.21203/rs.3.rs-595323/v1

License: (9) This work is licensed under a Creative Commons Attribution 4.0 International License. Read Full License 


\section{Abstract}

Purpose - The present COVID 19 virus has unexpected social problem with an overwhelming financial influence happening in each family circle. This research aimed to assess the overall influence of COVID 19 in selected cities in Ethiopia which has high population density, commercial, high local population movement and tourist attractive towns.

Design/Methodology/Approach - For a random sampling illustration 50,000 defendants are assessed through virtual mode commencing 17 cities of Ethiopia. For verifying the demonstrative of the statistics, demographic characters from online survey non behalf of time-based variations for each sample size. While survey in each city inadequate information collection is not bounded, studies for defendant's IP address not correspond to the nation; studies labeled as redundant, assessments with illegal replies, and studies irrational accomplishment period for each sample.

Findings - From this research one can understand the pecuniary influences increasing in alarming rate and incapable: out of the total respondents 45 percent of a family member missing their job and 59 percent of defendants report that a household member has closed their business. The rest households owning small businesses and among families with the lowermost income aforementioned for the pandemic, 71 percent information shows that a family member missing their job and 61 percent report that a household member has stopover their private business. Deteriorations in food safety and healthiness are among the incapable influences.

Originality/value - Virtual method of survey, random sampling and statistical regression analysis was better in signifying the COVID virus effect in different aspects

\section{Introduction}

Economic variation is one of the most important financial issues of our era (Girmay and Tesfay, 2020; Ousmane, 2020). Recent economic slumps, such as the Great Decline of 2008-2009, meaningfully increased economic variation (Heathcote et al., 2010; Black man et al., 2020; Piketty et al., 2019). Associated to other economic collapses, however, the COVID-19 pandemic is varying economic bustle through different channels and on a considerably more rapid timeline. To decrease the blowout of COVID19 pandemic, governments have applied strategies that need social distancing, the closing of nonessential businesses, travel limits and, and stay-at-home instructions (Fetzer et al., 2020; Briscese et al., 2020). Human relations that get-up-and-go the economy, for instance working collectively with in crowded places and relishing showbiz activities, have been discouraged, limited, or expelled in total. Households remain fulfilling through these actions, information's powerfully sustenance for them and vigorously look for evidence (Allcott et al., 2020; Bento et al., 2020; Adams et al., 2020). However these actions probably essential on behalf of communal healthiness, current substantiation beginning advanced nations advocates adverse pecuniary influences with in short period of time (Fetzer et al.,2017; Alon et al.,2020) and in count possibly excavate established difference for each low and high income communities 
(Emerta et al.,2020; Bento et al.,2020). These adverse impressions might be aggravated in low income countries since companies and the staff may be extremely susceptible for the reason of extraordinary stages of casualness and frailer administrative capability to reduce the pandemic. In this research employments has with in an extensive amount family study or survey to evaluate in what way the CORONA contagion lead to disparity financial impressions for families throughout the revenue circulation. The statistics confirms that imbalance and inadequate job sufferers and commercial terminations in adding possessions remain robust for lowermost revenue families. And the adverse effects decode into deteriorations for nutrition sanctuary and funding for strategies to accomplish the CORONA virus. Investigations on financial disparity is predominantly Significant for the case of Ethiopia. Even though disparity and deficiency deteriorated for the utmost current period proceeding towards the virus, the county nowadays has uppermost revenue unfairness throughout the Globe (Levy and Schady, 2013; Amarante et al., 2016; Ba'ez et al.,2019; Zaman et al.,2020). Besides a numerous part of peoples stayed exposed to sinking and return to low income level because of pecuniary tremors and this things are vital to know and evaluate the monetary influences of CORONA virus on families (Lulit et al., 2020; Milanovic, 2016; Brzezinski, 2018; Bartik et al.,2020), for instance, defines the probable unruly outcome of the disease throughout an extensive area of worldwide frugality, comprising employment resource besides the effects of trivial occupational termination and joblessness. This research accompaniments this exertion by computing short-period consequences this virus on jobless ness or victims and commercial endings which illustrates that this effects extra exacerbate variation with in the country. Moreover, small business spillovers and possibly intensify negative financial outcomes, so from this small business recommend that the approximations acquired remain a lower bound. The outcomes described in this paper might be valuable to notify viral alleviation strategy through signifying wherever the financial effects of comprehensive or excessive lockdowns remain predominantly great (Berg and Ostry,2011; Gershon et al., 2020).

\section{Methods}

\subsection{Strategy, Situation and Contributors}

For this research, the information was gathered an internet based survey from of the selected towns from Jan 122020 to Mar 3, 2020 predominantly standardized all over the regions towards permit aimed at combining the reactions as of entirely for the nations measured. The main aim of the assessment was to quantity and evaluates the financial and welfare affects that the present virus having on families for the selected cities with in the country Ethiopia. That's why, the survey concentrated on gathering statistics on employment marketplace consequences, monetary condition, and communal platform matriculation. The study collected evidence on starvation, poverty, absences of vital property's, and contract using strategies intended at reducing the blowout of CORONA Pandemic. A photocopy of survey enables to originate in the Additional Evidence unit. Families in 17 towns were collected and examined: 10 near to capital city of

Addis and selected regional centers (Addis Ababa, Adama, Bahirdar, Mekele, Semera, Jigjiga, Assosa, and Hawassa), 4 Town from each region (Dessie, Gonder, Moyale, and Diredawa), and 5 from zonal coverage 
(N/Gonder, E/Shewa, N/Wollo, N/Shewa, Gamo and Bale). The assessment and data collection was started on March 27, 2020 at the capital city of Ethiopia, Addis Ababa also gradually moved to other cities in accordance with the distance from the capital city up to April 17, 2020.

\subsection{Sampling and Validation}

Similar enrolment approaches stayed and adopted in different regions. This paper enlisted contributors whose ages are 18 years old and overhead with the help of rewarded announcements on public and social mass media. Involvement for the assessment was virginally volunteer. The announcements using key terms through wide-ranging demand, for instance sport/football/ or the designations of native stars, neglect to choose contributors according to CORONA pandemic perception, opinion, Attitude and point of view (additional information's enclosed and appear in the Additional Evidence unit). While survey in each city inadequate information collection is not bounded, studies for defendant's IP address not correspond to the nation; studies labeled as redundant, assessments with illegal replies, and studies irrational accomplishment period for each sample. The ending sample comprises about 50,000 respondents out of accomplished replies. For enclosing the questionnaires was arbitrary flanked by two week, three weeks, and one month? Work percent for a recollection time of two week and one month respectively. From the countries (e.g., rates of job loss and business closure).

\subsection{Analysis of Statistical Data}

This research verifies evocative figures for getting significant results combined to each defendant bang that which family member Topographical closure, inspection among these 92 percent of states was examined. For verifying the demonstrative of the statistics, demographic characters from online survey non behalf of time-based variations for each sample size. Exclusion is segment delivers particulars on the stages occupied to approximate values for the online review and the verification part. Were linked to nationwide demonstrative family studies. Figure 3 gives that re-value remarks. Associated with parallel figures in the selected towns in USA (where 43 percent of small businesses in the country were closed and here to hand job loss existed (Alon et al., 2020).

\section{Results}

\subsection{CORONA and Loss of Livelihood}

The data explains 45 percent of defendant's explosion that a family members or affiliate. Family's commentary work fatalities drops monotonically in the month of January 2020 revenue, prior to the start of the virus as shown in Fig. 1.

\subsection{Injury of Livelihood and Discrimination}

The general effects vague highly imbalance crosswise revenue stages preceding to the virus. From the gradient coefficient in Fig. 2, it's possible to know percentage value rise in the portion of private employees in a nation growths the probability that a defendant missing their living by 0.54 percent $(p-$ 
value $=0.005)$ an R-squared of 42 percent. Since casualness charges remain great in utmost emerging nations, this outcome offers a unique clarification aimed at how and why employment marketplaces in emerging states are predominantly difficult achievement throughout the catastrophe.

Fact approximations and 95\% confidence limit for carryout regression between labor marketplace result in pointers and nation constant consequences Every point signifies the portion of defendants who reply that a family member missing an occupation or locked a commercial center.

Table 1

Mutilation of peoples on the time of CORONA pandemic which connected to variations in diet and strategy funding.

\section{Section 1: Influences of revenue, nutrition safety as well as policy support}

\begin{tabular}{|llll|}
\hline & A & B & C \\
\cline { 2 - 4 } & Reduced revenue & Died starving & feeds fewer well being \\
\hline $\begin{array}{l}\text { Missing work locked } \\
\text { business }\end{array}$ & 0.231 & 0.127 & 0.085 \\
\hline Observations & 0.007 & 0.008 & 0.008 \\
\hline Corrected $\mathrm{R}^{2}$ & 180,058 & 182,076 & 173,956 \\
\hline $\begin{array}{l}\text { Section 2: Influences happening Transfer or } \\
\text { strategy care }\end{array}$ & 0.35 & 0.602 & 0.43 \\
\hline & $\mathrm{A}$ & & \\
\hline & Support/Advance & $\begin{array}{l}\text { Administration } \\
\text { primacy }\end{array}$ & $\begin{array}{l}\text { Closing greater than a } \\
\text { month }\end{array}$ \\
\hline Lost job closed business & 0.225 & -0.027 & -0.042 \\
\hline & 0.008 & 0.008 & 0.01 \\
\hline Observations & 185,075 & 192,085 & 122,409 \\
\hline Corrected $\mathrm{R}^{2}$ & 0.389 & 0.425 & 0.54 \\
\hline $\mathrm{p}<0.1$ & $\mathrm{p}<0.05$ & " $\mathrm{p}<0.01$ & \\
\hline
\end{tabular}

The influences on work fatalities and commercial closings interpret into decreases in revenue. Totally, 71 percent of defendants show they imagine their family revenue in April 2020 to be lesser than their January 2020 family revenue. 31 percent of defendants show family revenue which is a smaller amount as compared to the nationwide. Once-a-month lowest income for the month of January 2020 and $56 \%$ of 
families depicts that they imagine their family wages less as compared to the countrywide lowest income in April 2020. Figure 3 describes the spreading of family revenue estimated in April 2020 is a left wise shift for the spreading of January 2020 family revenue. For instance, the share of households with incomes marginally above the national, the minimum income drops in between the month of January and April 2020 signifying that numerous susceptible families presume to tumble to hunger and starvation.

Table 1 shows regression constants taking the comparisons among damage of livelihood and its consequences at a time of pandemic. The column value rumors outcomes of a regression of the prominent and dependent parameters on an indicator of weather any family amount whichever missing a work or locked a commercial a trajectory of covariates.

\subsection{Diet and Strategy Provision}

The existing statistics recommend that work sufferers and commercial closings enables decreases in wellbeing and nutrition safety. From Table 1 Columns 2 and 3 of Sect. 1 specifies that families through a work injury or commercial closing are 13 percentage points ( $p$-value $<0.01)$ probable to agonize as of starvation and 8 percent values ( $p$-value $<0.01$ ) additional probable to must a fewer well food comparative to their food preceding to the virus. This magnitude signifies about 25 out of a hundred rises starting the attuned be an average of informed by families that bang not taking mislaid their means of support (40 percent). Column 1 of Sect. 2 of Table 1 describes families who missing their livings at the time of the catastrophes are 22 percentage values ( $p$-value $<0.01$ ), expected to collect transmissions from families or friends. This discovery suggests that families collaborate crosswise revenue stages to even the adverse financial influences of the virus. Seventy percent of defendants' replies family revenue a smaller amount as compared to the countrywide lowest income in January 2020 also reported as family affiliate established a flair or advance from a colleague or family member 95 percent confidence intervals for value approximations also have for the portion of defendant's subsidiary spreading closing strategies in comparisons with the amount of times later the major CORONA event in the nation. Statistics is slanted by means of inside- and out of country hefts. In the month of January 2020 revenue a lesser amount comparable to the nationwide lowest income likewise a family affiliate providing a knack or advance, associated to 57 percent of families with the uppermost wages in January 2020 who shows similar which is nearly Thirty percent of families. And Fig. 4 shows the expansion of closing rules due to COVID 19 and the corresponding missing of their lives.

\section{Conclusions}

The statistics endorse two vital clarifications aimed upper susceptibility for residents with in Ethiopia through great ranks in addition to lack of formality. Principally, nature of strategies supports and avoid blowout during COVID 19 with probable and mark casual labors than proper labors (Fig. 2). The assessment detentions statistics together as of cities deprived of imposed movement limit guidelines and regulations, For instance Addis Ababa, obligatory confinements and closings unnecessary selling, for Gonder and Moyale. Since utmost of the casual and private worker tend labor in occupations that type 
them disposed to interaction through extra persons for individuals in the selling or facilities segments, Though extra assessment is desired, a numeral of research require establish that current dissimilarity is destructively connected with upcoming financial growing (Kalle, 2020; Singano, 2014) and in specific, disparity ambitious by the lesser termination of the income circulation maneuvers economic growth. The uneven financial influences of short period communal wellbeing virus can require longstanding corollaries for financial increment.

\section{Abbreviations}

COVID

CO- Corona; VI- Virus; D- Disease IP:Internet protocol; USA:United States of America; R ${ }^{2}$ - Regression coefficient; CORONA:City of Repugnant Odorous Native Animals

\section{Declarations}

\section{Acknowledgements}

The authors would like to acknowledge Health officers and interviewees in each city for their input into this research, in the respective data collection and data analysis phases.

\section{Authors' contributions}

Abebe Temesgen Ayalew conceptualized the study, developed the interview guide and conducted some interviews and Elsabet Getachew Aynalem checked and Analyzed the data and prepare drafted the manuscript and both author approved the final manuscript

\section{Funding}

This study did not receive specific funding.

\section{Availability of data and materials}

The datasets during and/or analyzed during the current study are available from the corresponding author on reasonable request.

\section{Ethics approval and consent to participate}

The study was reviewed and approved by the Institutional Review Board of Institute of Health (Ref.No. IRB000123/20). Respondents were presented with brief information about the study purpose and the process of the study, and consented in written to participate in the survey.

\section{Competing interests}


All authors declare no competing interests as defined by $\mathrm{BMC}$, or other interests that might be perceived to influence the results and/or discussion reported in this paper.

\section{Corresponding author}

Correspondence to Abebe Temesgen Ayalew

\section{References}

1. Adams-Prassl A, Boneva T, Golin M, Rauh C. (2020) Inequality in the impact of the coronavirus shock: Evidence from real time surveys;

2. Ahn YY, Simon K. (2020) Evidence from internet search data shows information-seeking responses to news of local COVID-19 cases. Available.https://www.pnas.org/content/early 05/01/ 2005335117

3. Allcott H, Boxell L, Conway JC, Gentzkow M, Thaler M, Yang DY. (2020) Polarization and public health: Partisan differences in social distancing during the coronavirus pandemic; NBER Working Paper No. 26946.

4. Alon TM, Doepke M, Olmstead-Rumsey J, Tertilt M. (2020) the Impact of COVID-19 on Gender Equality National Bureau of Economic Research;

5. Amarante V, Galva'n M, Mancero X. (2016) Inequality in developing countries Latin America: A global measurement https:// doi.org/10.18356/bf11809a-en 26947.

6. Ba'ez JE, Fuchs A, Rodríguez-Castela'n C. (2019) Trembling out of bed financial development. Combined shockwaves in South America and Caribbean countries

7. Bartik AW, Bertrand M, Cullen ZB, Glaeser EL, Luca M, Stanton CT. (2020) How Are Small Businesses Adjusting to COVID-19? Early Evidence from a Survey National Bureau of Economic Research; 26989

8. Berg AG, Ostry JD. (2011) Inequality and Unsustainable growth: Two sides of the same coin?

9. Bento Al, Nguyen T, Wing C, Lozano-Rojas F,Ahn YY, Simon K. (2020) Evidence from internet search data shows information-seeking responses to news of local COVID-19 cases.Available:https://www.pnas.org/content/earl/05/01/ 2005335117.

10. Blackman A, Iba'ñez AM, Izquierdo A, Keefer P, Moreira MM, Schady N, et al. (2020) La polı́tica publica frente al Covid-10;. IDB Policy Note

11. Briscese G, Lacetera N, Macis M, Tonin M. (2020) Compliance with COVID-19 social-distancing measure in Italy: The role of expectations and duration; NBER Working Paper No. 26916

12. Brzezinski M. (2018) Income inequality and the Great Recession in Central and Eastern Europe economic Systems: 42 (2): 219-247.

13. Emerta Aragie, Alemayehu Seyoum Taffesse, Seneshaw Tamru (2020) The Short-term Economy through External, An economy wide multiplier model analysis, Sector Channels, Strategy Support Program Working Paper 154

14. Fetzer T, Witte M, Hensel L, Jachimowicz JM, Haushofer J, Ivchenko A, et al. (2020) Global behaviors and perceptions at the onset of the COVID-19 pandemic 
15. Fetzer T., Hensel L., Hermle J., Roth C. (2017) Coronavirus perceptions and economic anxiety. Review of Economics and Statistics, 1-36

16. Gershon, David and Lipton, Alexander and Levine, Hagai (2020) Managing covid-19 pandemic without destructing the economy. arXiv preprint arXiv:.10324; .

17. Girmay Adhena, Tesfay Temesgen.(2020) Perceived Stress Associated with COVID-19 Pandemic in Korem, Tigray, Ethiopia: Science journal of public health. Volume 9:26-37 ;

18. Heathcote J, Perri F, Violante GI. (2010) Unequal we stand: An empirical or numerical interpretation and analysis of economic inequality in the United States, 1967-2006. Review of Economics Dynamics 13 (1): 15-51. https://doi.org/10.1016/j.red.2009.10.010

19. Kalle Hirvonen. (2020) Economic impacts of COVID-19 pandemic in Ethiopia: A review of phone survey evidence, International food policy and research Institute

20. Levy S, Schady N. (2013) Latin America's social policy challenge: Education, social insurance, and redistribution. Journal of Economic Perspectives; 27 (2): 193-218.

21. Lulit Mitik Beyene, Tadele Ferede and Getachew Diriba (2020) the economy wide impact of the COVID-19 in Ethiopia: Policy and Recovery options, Policy Working Paper, ISBN: 9789994454 76-1

22. Milanovic B. (2016) Global Inequality in This Century and the Next In: Global inequality: A new approach for the age of globalization. Harvard University Press

23. Ousmane Dione. (2020) Tackling the impacts of COVID-19 is imperative to Ethiopia's journey to prosperity;

24. Piketty T, Yang L, Zucman G. (2019) Capital accumulation, private property, and rising social inequality in China 1978-2015. American Economic Association Review on inequality; 109 (7): 24692496.

25. Zaman K Taeen and Islam Hiya and Khan Asir Newaz and Shweta Dipita Saha and Rahman Ahsab and Masud Jaasia and Araf Yusha and Sarkar Bishajit and Ullah Md Asad (2020) COVID-19 Virus effects on economy, social value and social interaction through creation of Load on Worldwide Economy

\section{Figures}




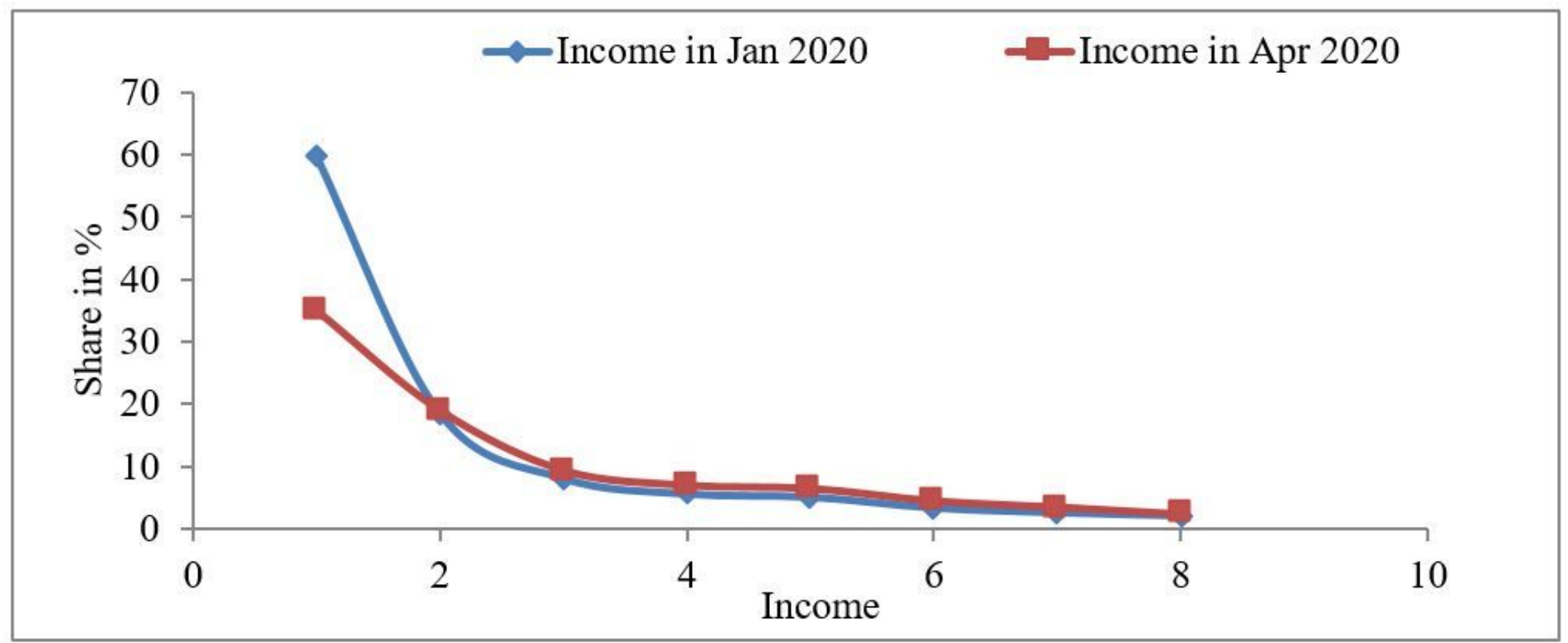

Figure 1

Increased rate of job less ness and commercial closing amongst families for low income range

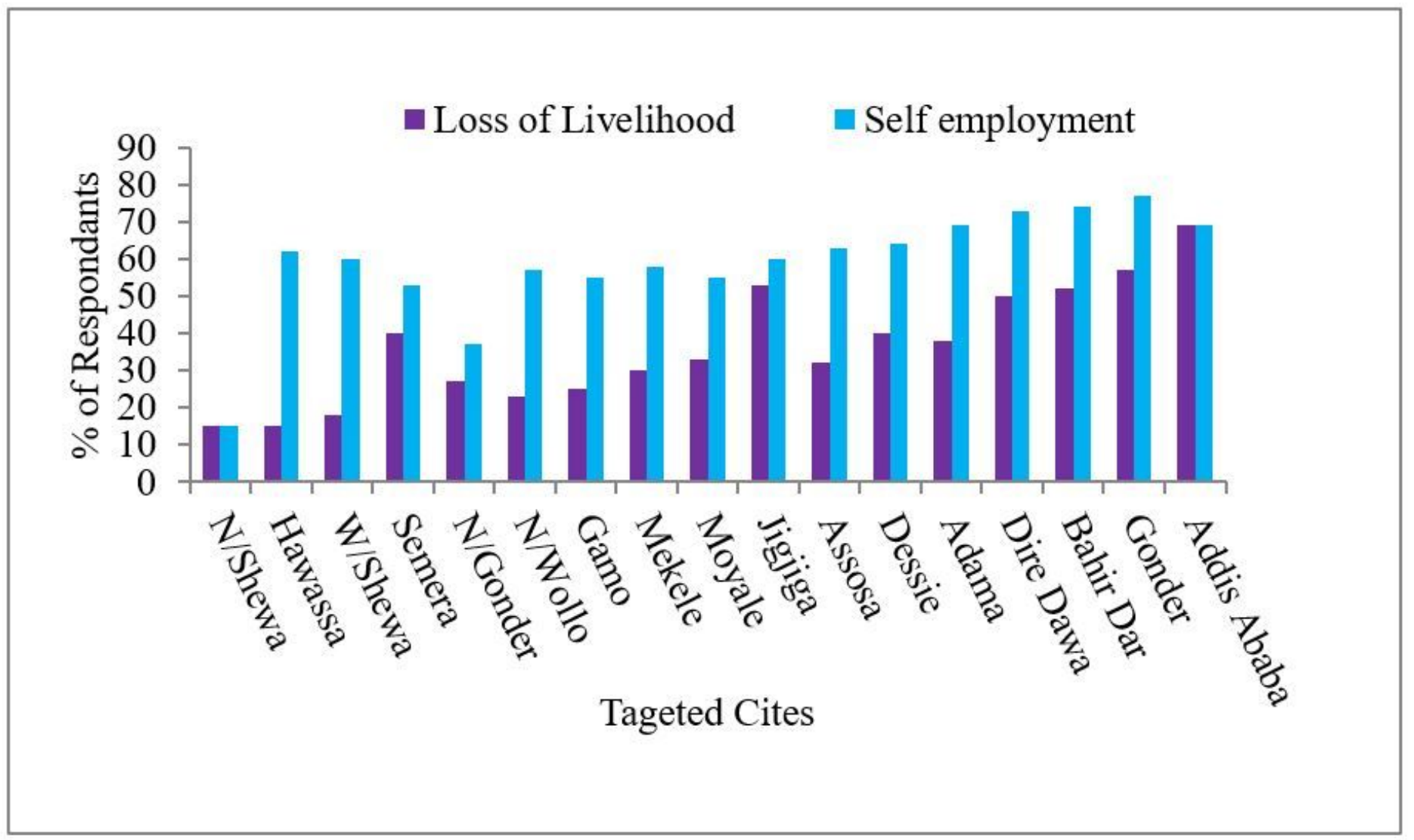

Figure 2

Upper scores of livelihood damage in nations with great casualness. 


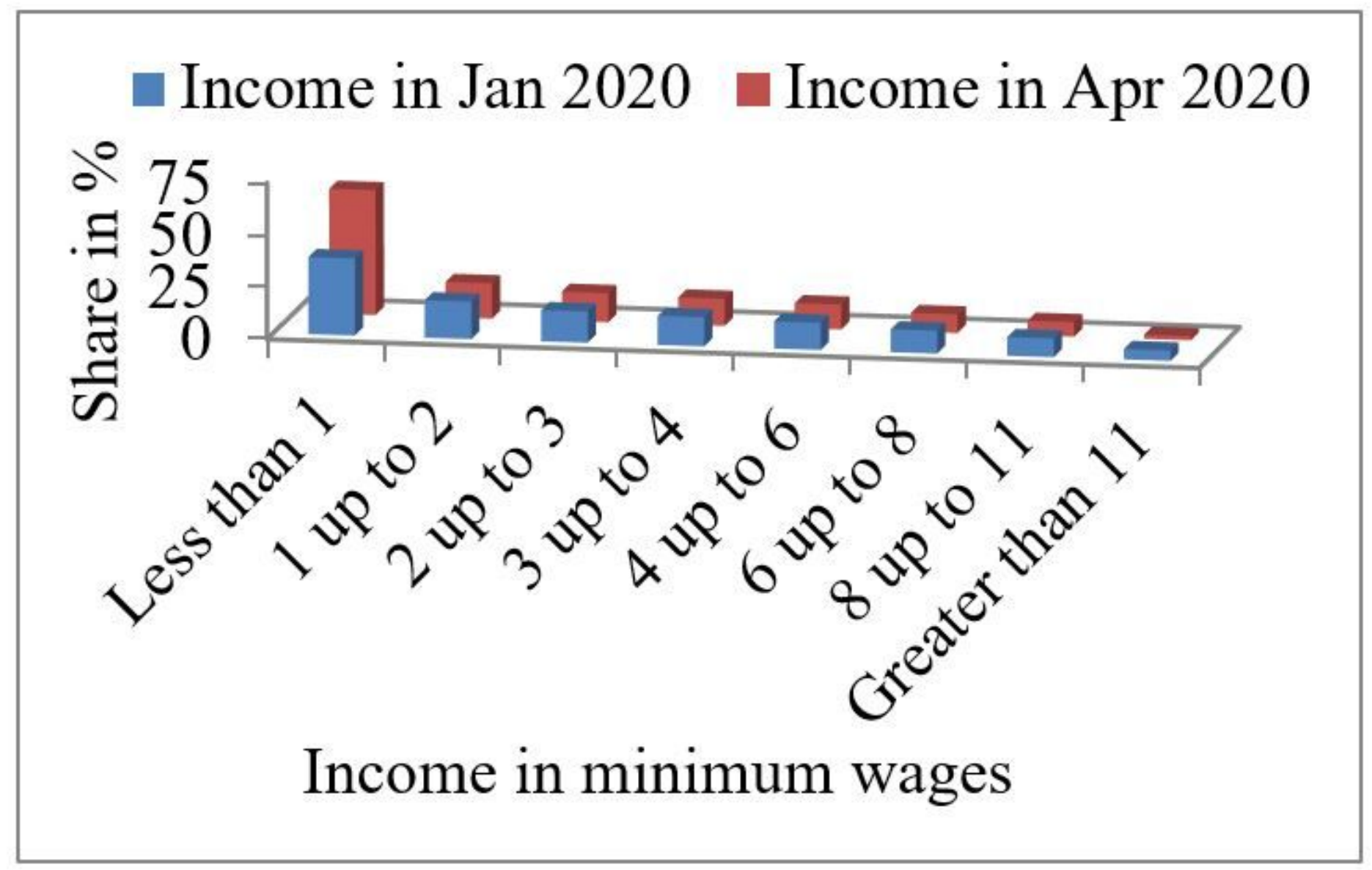

Figure 3

The portion of families in the lowest portion of the revenue circulation is estimated to intensification. 


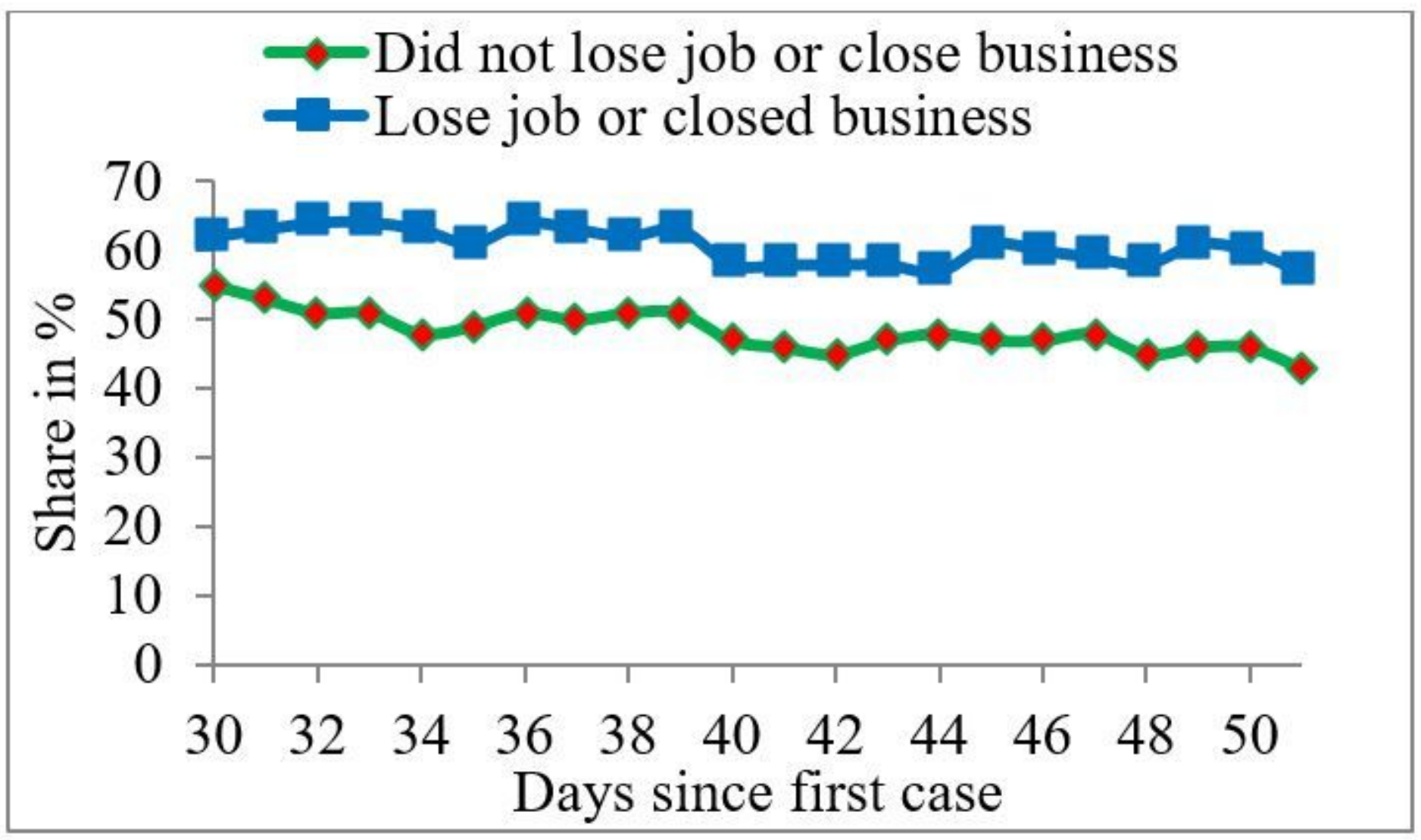

Figure 4

Sustenance aimed at spreading closing rules drops extra amongst families who missing their livings.

\section{Supplementary Files}

This is a list of supplementary files associated with this preprint. Click to download.

- AdditionalFile1.docx 